\title{
COMPARISON OF ELECTROSPINNING AND WET-SPINNING METHODS FOR THE PRODUCTION OF CHITOSAN-BASED COMPOSITE FIBERS
}

\author{
PRIMERJAVA MED ELEKTROSPINIRANJEM IN METODO \\ MOKREGA SPINIRANJA ZA PROCESIRANJE KOMPOZITNIH \\ VLAKEN NA OSNOVI HITOZANA
}

\author{
Elena Dresvyanina ${ }^{1}$, Alexandra Yudenko², Inna Lebedeva ${ }^{1}$, Pavel Popryadukhin ${ }^{1}$, \\ Irina Dobrovolskaya ${ }^{1}$, Vladimir Yudin ${ }^{1}$, Pierfrancesco Morganti ${ }^{3}$ \\ ${ }_{1}^{1}$ Peter the Great St. Petersburg Polytechnic University, Polytechnicheskaya 29, 195251 St. Petersburg, Russia \\ ${ }^{2}$ Saint-Petersburg State University of Industrial Technologies and Design, B. Morskaya 18, 191186 Saint-Petersburg, Russia \\ ${ }^{3}$ University of Campania "Luigi Vanvitelli", Viale Abramo Lincoln n. 5, Caserta, Italy \\ elenadresvyanina@gmail.com
}

Prejem rokopisa - received: 2017-07-03; sprejem za objavo - accepted for publication: 2017-10-03

doi:10.17222/mit.2017.116

\begin{abstract}
The influence of chitin nanofibrils on the production of chitosan-based fibers is described in the article. The chitosan-based fibers and composite fibers were prepared from an aqueous solution of 2-\% acetic acid using the coagulation method. The incorporation of $0.1-0.3 \%$ of mass fractions of CNs into the chitosan matrix contributed to an increase in the mechanical properties of the composite fibers. The chitosan nanofibers were spun with electrospinning from a 70-\% acetic-acid aqueous solution of chitosan containing $10 \%$ of mass fractions of PEO and 1-30\% of mass fractions of CNs. The introduction of CNs into chitosan solutions accelerates considerably the quality of nanofibers at the electric field and decreases the amounts of defects in them. The optimal concentration of CNs for producing defect-free chitosan nanofibers was $20 \%$ of mass fractions. Keywords: chitosan, chitin nanofibrils, wet spinning, electrospinning
\end{abstract}

V članku avtorji opisujejo vpliv hitinskih nanovlakenc na procesiranje vlaken na osnovi hitozana. Vlakna na osnovi hitozana in kompozitna vlakna so pripravljali iz $2 \%$ vodne raztopine ocetne kisline s koagulacijsko metodo. Vnos od 0,1 do 0,3 masnih odstotkov hitinskih nanovlakenc (angl.: CNs) v hitozansko matriko je prispeval k izboljšanju mehanskih lastnosti kompozitnih vlaken. Hitozanska nanovlakna so spinirali (zapredli) z elektrospiniranjem iz $70 \%$ vodne raztopine ocetne kisline hitozana, ki je vseboval 10 masnih \% PEO (angl.: Poly Ethilen Oxide) in 1-30 masnih \% CNs. Vnos CNs v hitozansko raztopino je znatno izboljšal kvaliteto nanovlaken v električnem polju in zmanjšal količino napak v njih. Ugotovljena optimalna koncentracija CNs je bila 20 masnih odstotkov pri procesiranju hitozanskih nanovlaken brez napak.

Ključne besede: hitozan, hitinska nanovlakenca, mokro in suho mešanje

\section{INTRODUCTION}

Chitosan, a derivative of the natural polysaccharide chitin, exhibits a biocompatibility, biodegradability, bactericidal activity and absence of toxicity. Due to such properties, chitosan-based materials find a lot of applications in medicine. Two methods such as wet spinning and electrospinning are used for the preparation of chitosan-based materials. Wet spinning is widely used for polysaccharides. ${ }^{1}$ Chitosan is a typical polysaccharide and fiber preparation from chitosan is possible only with the precipitation of the solution followed by washing and drying. ${ }^{1,2}$ Recently, the interest in fibers with a diameter of tens or hundreds of nanometers has grown. These nanofibres can be obtained with electrospinning. The materials based on chitosan nanofibers can be used as tissue-engineering drugs consisting of a polymer matrix and stem or somatic cells. ${ }^{3}$

The aim of this work is to compare the influence of chitin nanofibrils on the wet spinning of microfibers and electrospinning of nanofibers, as well as on their structures and properties.

\section{EXPERIMENTAL PART}

Chitosan with DD $=92 \%, \mathrm{M}_{\mathrm{w}}=190 \mathrm{kDa}, \mathrm{PD}=1.6748$ (Bioprogress, Russia) and chitosan with DD $=86 \%$, $M_{\mathrm{w}}=210 \mathrm{kDa}, \mathrm{PD}=1.0752$ (Fluka Chemie, Bio Chemika line) were used for preparing chitosan fibers. Chitin nanofibrils (CNs, Mavi Sud s.r.l, Italy) and PEO (Unioncarbide, $\mathrm{Mw}=9 \times 10^{5}$ ) were used as the filler for obtaining the bioresorbable composite fibers and improving their formation.

The chitosan microfibers as well as composite microfibers modified with $\mathrm{CNs}$ were prepared from a 2-\% acetic-acid aqueous solution of chitosan using the coagulation method. ${ }^{1,2}$ The chitosan nanofibers were prepared by electrospinning from a $70-\%$ acetic-acid aqueous solution of chitosan containing PEO and CNs. ${ }^{4}$

Rheological studies were performed on a Physica MCR 301 rheometer (Anton Paar) at $20{ }^{\circ} \mathrm{C}$. The electrical conductivities of chitosan solutions and their mixtures were determined with a Seven Compact S230 electrometer (Mettler Toledo Co., Switzerland). Sur- 
face-tension values were found via a drop-shape-analysis tensiometer (DSA 4) (KRUSS, Germany) using the hanging-drop method. The structures of the fibers and nanofibers were investigated with a Supra 55VP scanning electron microscope. Measurements of the mechanical properties of the produced fibers were carried out on an Instron 5943 testing machine.

\section{RESULTS AND DISCUSSION}

Dependencies of the viscosity $(\eta)$ on the shear rate $(\dot{\gamma})$ for chitosan solutions have a non-linear behavior. In the chitosan solution without the filler (Figure 1), a decrease of viscosity was observed at the shear rate of $10 \mathrm{~s}^{-1}$ or more. Increasing the concentration of the polymer in the solution leads to an increase in the effective viscosity. The optimal concentration of chitosan in the solution was 6-6.5\% for sample 1 and $4 \%$ for sample 2. Fibers with the best mechanical properties were prepared with the $213 \mathrm{kDa}$ chitosan sample and $\mathrm{PD}=1.0752$, whose fibers have a strength of $220 \pm 18 \mathrm{MPa}$ and Young modulus of $0.9 \pm 0.12 \mathrm{GPa}$.

The threshold value of the shear rate, at which the dependence of $\eta(\dot{\gamma})$ becomes non-linear, shifts to smaller values with an increasing content of CNs (Figure 1). For the mixture containing $20 \%$ of mass fractions of the chitin filler, the dependence of $\eta(\dot{\gamma})$ becomes linear over a wide range of shear rates. Generally, the decrease in the viscosity upon an increase in the shear rate is related to the destruction of the initial structure of the polymer solution and the creation of a newly oriented structure, which indicates a transition from the isotropic state to the anisotropic one. An increase in the $\mathrm{CN}$ content in the chitosan solution is accompanied by an increase in the viscosity, which is especially noticeable at low shear rates. This indicates a good interaction of the CNs with chitosan macromolecules and the formation of the cluster structure of the filler. Thus, the wet spinning of composite chitosan/chitin fibers at a very low $\mathrm{CN}$

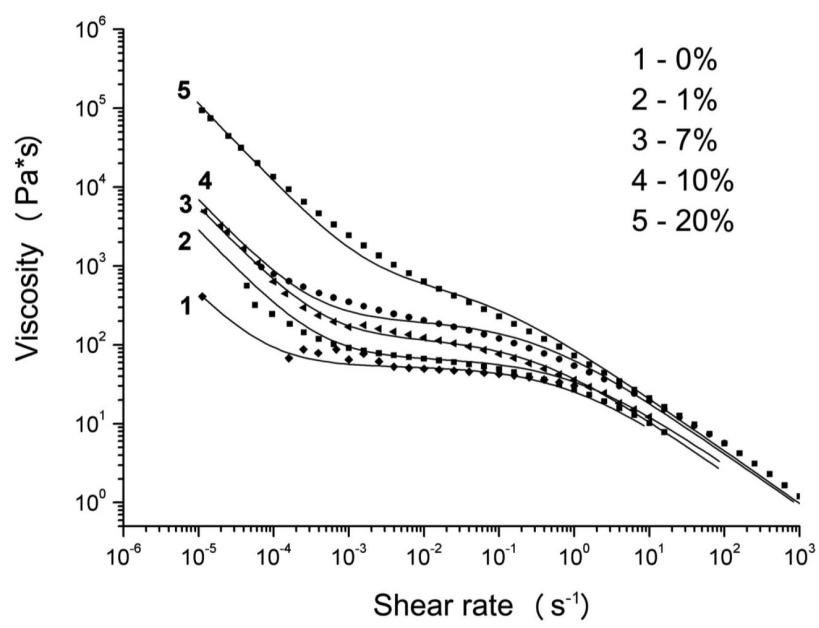

Figure 1: Dependences of viscosity on the shear rate for chitosan solutions with different contents of CNs

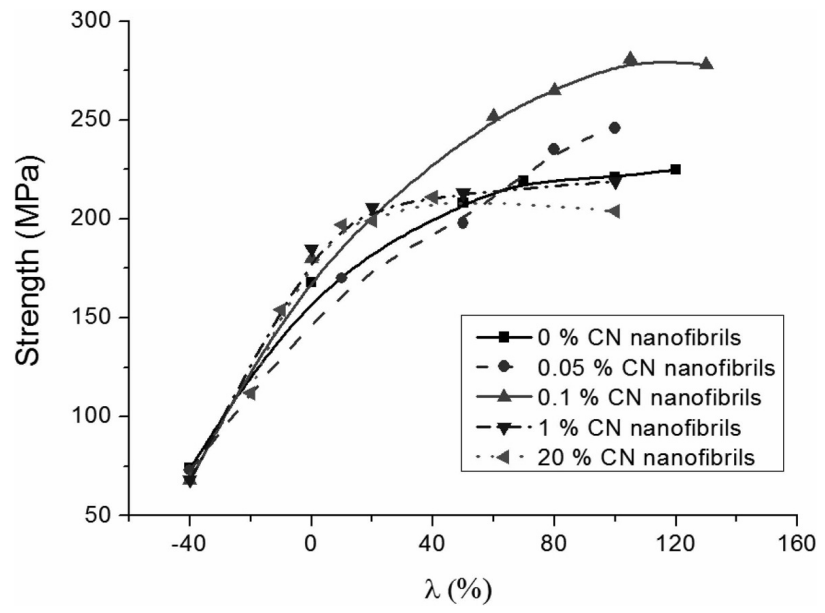

Figure 2: Dependences of the tensile strength of chitosan and chitosan/chitin composite fibers on orientation drawing $\lambda$ for different contents of CNs

content $(<1 \%)$ should be close to the production of pure-chitosan fibers.

The strength of the chitosan fibers (without a filler) grows considerably with an increase in drawing up to $\lambda \sim 50 \%$ (Figure 2). Further drawing does not affect the fiber strengthening. The strength of the composite chitosan/chitin fibers containing a small quantity (0.05-0.3\% of mass fractions) of the filler increases monotonically with the drawing up to $\lambda \sim 120 \%$. An increase in the content of CNs in the composite fibers above $1 \%$ of mass fractions significantly changes the nature of the $\sigma(\lambda)$ dependence. An increase in the strength ceases at $\lambda \sim 20 \%$ just as it does in the case of unfilled chitosan fibers. The incorporation of $0.1-0.3 \%$ of mass fractions of CNs into the chitosan matrix contributed to an increase in the strength (Figure 3) and Young modulus of the composite fibers due to the additional orientation of the chitosan macromolecules on the $\mathrm{CN}$ surfaces. ${ }^{2}$

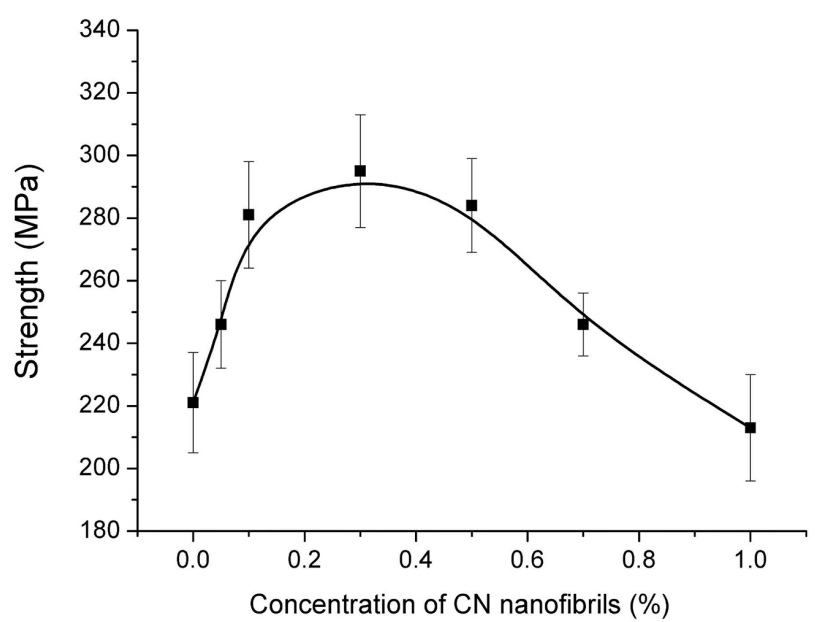

Figure 3: Dependences of the tensile strength of chitosan/chitin composite fibers on the content of $\mathrm{CNs}$ 
The preparation of the fibers from chitosan with electrospinning is very difficult. It is known that to spin chitosan-based nanofibers, water-soluble fiber-forming polymers, such as PEO, PVA or methyl cellulose, are added to the solution. ${ }^{3}$

It was shown that the electrical conductivities of chitosan solutions and liquid mixtures containing PEO are $2-4 \mathrm{mS} / \mathrm{cm}$, that is, three to four orders of magnitude higher than the values for polymers with good spinning abilities in electric fields (aliphatic copolyamides and PVA) ${ }^{4}$ The introduction of PEO causes a slight decrease in the electrical conductivity of a solution with a chitosan concentration of $7 \%$ of mass fractions, but has almost no effect on the electrical conductivities of solutions containing small amounts of chitosan $(3 \%$ or $4 \%$ of mass fractions). The surface-tension coefficients of the chitosan solutions with concentrations of 3-4\% of mass fractions remain practically the same after the addition of small amounts of PEO. At the same time, the addition of PEO to the 3- and 4-\% of mass fractions of chitosan solutions has no effect on surface-tension coefficients $\gamma$. For a 5-\% of mass fractions of chitosan solution, the surface-tension coefficient increases with an increase in the PEO content. Note that these values are higher than the values for the solutions of PEO and aliphatic copolyamide, for which $\gamma$ is $\sim 30 \mathrm{~N} / \mathrm{m}$.

All these studies were carried out using chitosan sample 1 that was optimal for electrospinning. To improve the process, the $\mathrm{CNs}$ were incorporated into the chitosan solution as well. The conductivity of the mixed solution likewise increases insignificantly with the addition of $1-10 \%$ of mass fractions of CNs with respect to chitosan. ${ }^{4}$

From the above data, it follows that the surfacetension value exhibits a jump-like decrease when the

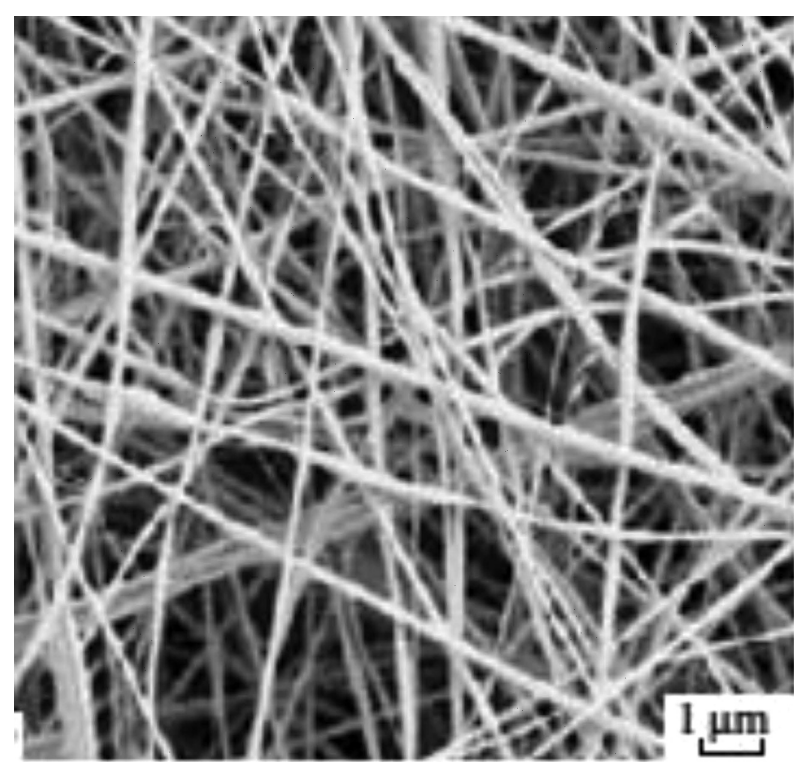

Figure 4: Micrograph of a material obtained via the electrospinning of a $4-\%$ chitosan solution containing $10 \%$ of mass fractions of PEO + $20 \%$ of mass fractions of CNs concentration of CNs in the pure solution is $1 \%$ of mass fractions, while an increase in the concentration of CNs leads to a slow decrease in the surface tension. However, for the solutions with the same concentrations of CNs and chitosan and an addition of $10 \%$ of mass fractions of PEO, we can observe the disappearance of the jumplike decrease, while the level of the surface tension becomes constant, regardless of the concentration of CNs.

The addition of nanofibrils to the PEO-containing chitosan solution, on the one hand, increases the viscosity and, on the other hand, considerably increases its dependence on the shear rate, relative to the solutions free of chitin nanofibrils.

The incorporation of $\mathrm{CNs}$ into chitosan solutions stabilizes the electrospinning of nanofibers and makes it possible to reduce the content of PEO in nanofibers.

After the introduction of less than $20 \%$ of mass fractions of PEO, the amounts of defects (drops, microspheres) in nanofibers increase considerably. Moreover, these defective nanofibers are formed only at a very low polymer-flow rate, while an increase in this rate leads to the formation of even larger drop-like defects, causing a substantial decrease in the fraction of nanofibers.

After the introduction of CNs into the chitosan solution containing $10 \%$ of mass fractions of PEO, defectfree structures of nanofibers may be obtained (Figure 4).

\section{CONCLUSIONS}

Chitosan-based fibers and composite fibers were prepared from an aqueous solution of 2-\% acetic acid with the coagulation method. The incorporation of $0.1-0.3 \%$ of mass fractions of CNs into the chitosan matrix contributed to an increase in the strength and Young modulus of the composite fibers. The chitosan solutions containing CNs exhibited the necessary rheology characteristics, preserving the laminarity of the jet in the coagulation bath after the solution flows through the die hole.

The introduction of CNs into chitosan solutions accelerates considerably the quality of the nanofibers at the electric field and decreases the amounts of defects in them. It was found that the optimal concentration of $\mathrm{CNs}$ for producing defect-free chitosan nanofibers is $20 \%$ of mass fractions.

The obtained fibers may be used as the matrices for cell-replacement technologies and tissue engineering as well as the materials for wound dressings and hemostatic material.

\section{Acknowledgment}

The authors are grateful to the Russian Science Foundation Grant № 14-33-00003 for the financial support. 


\section{REFERENCES}

${ }^{1}$ H. Tamura, Yu. Tsuruta, K. Itoyama, W. Worakitkanchanakul, R. Rujiravanit, S. Tokura, Preparation of chitosan filament applying new coagulation system, Carbohydrate Polymers, 56 (2004), 205-211, doi:10.1016/j.carbpol.2004.02.003

${ }^{2}$ V. E. Yudin., I. P. Dobrovolskaya, I. M. Neelov, E. N. Dresvyanina, P. V. Popryadukhin, E. M. Ivan'kova, V. Yu. Elokhovskii, I. A Kasatkin, Wet spinning of fibers made of chitosan and chitin nanofibrils, Carbohydrate Polymers, 108 (2014), 176-182, doi:10.1016/j.carbpol.2014.02.090

${ }^{3}$ J. D. Schiffman, C. L. Schauer, A Review: Electrospinning of Biopolymer Nanofibers and their Applications, Polymer Reviews, 48 (2008), 317-352, doi:10.1080/15583720802022182

${ }^{4}$ I. P. Dobrovolskaya, I. O. Lebedeva, V. E. Yudin, P. V. Popryadukhin, E. M. Ivan'kova, V. Yu. Elokhovskii, Electrospinning of Composite Nanofibers Based on Chitosan, Poly(ethylene oxide), and Chitin Nanofibrils, Polymer Science, Series A, 58 (2016) 2, 246-254, doi:10.1134/S0965545X1602005X 